\title{
Utilization of Selected Methods of Managerial Economics in Aviation Companies
}

\author{
Soňa Hurná \\ Technical University of Košice, Faculty of Aeronautic \\ Košice, Slovakia \\ sona.hurna@tuke.sk
}

\author{
Pavol Bajusz \\ Technical University of Košice, Faculty of Aeronautic \\ Košice, Slovakia \\ pavol.bajusz@tuke.sk
}

\begin{abstract}
The article is focused on the areas of management in aviation companies by way of applying selected methods of managerial economics, applicable under the constantly changing conditions entailing high level of risks. Attention is paid separately to the characterizing the external environment, applying the systems-based views, balance sheet analysis and controlling. The core of the publication is on selected methods representing the pillars of company economics and can be adapted by managers with purely technical background.
\end{abstract}

Keywords-Economics, management, levels of control, methods of economical analysis, managerial skills

\section{INTRODUCTION}

World economy is undergoing multitudes of changes as a result of technological advance, development of highlydynamic branches of the national economies offering high lave of the added value, globalization as well as expansion of the rapid-rise branches, changing technology, development of several changes as well as by the development of transportation infrastructure adding up the rate of growth in logistical processes. In most of the aspects, situation in our local economy has also changed as a result of Slovakia's entry to the EU. The unified European market has opened the potentials for entrepreneurship in cooperation with other countries as well. An era frequently marked as the one of new economy, knowledgebased economy, digital economy, post-industrial etc.

Despite of these facts one has to emphasize that there is no „worse “or ,better “economy. There is only one, which is to be well understood so as to be knowledgeable of the measures to be adopted in a company. As by P. Drucker, only those companies will survive, which pay due attention to markets situation, innovation, productivity, cultivating labor force and financial results of the company. (Drucker,2015) The approach is important also for the reason that one has to remain focused not only the potentials but the limitations of managers. It involves their capability of handling the changeable and unchangeable factors affecting their firms, often known as competition, regulatory framework, trends of globalization etc. Managers cannot but act on the changeable ones and learn foreseeing those that cannot be changed.
The current era is setting high standards for managers active in all levels of company management, with task and competencies tailored to that leader within. The authors have chosen the very specific requisites inevitable for managers to handle regardless of their level of assignment. Primarily, the issue involves three based managerial skills: system based thinking, overview of economic potential, tool of monitoring and achieving the goals sets. As it entails requirements beyond the well-known framework of managerial functions, the authors 'intention are to analyze the prerequisites giving illustrative explanations, understanding the economic reports revealing the economic health of the company. Their understanding will subsequently lead to right decisions, which will find reflection in overall economic results of the company.

\section{SELECTED METHODS AND APPROACHES OF ASSESSING ECONOMIC SITUATION IN AVIATION COMPANIES}

\section{A. System-based thinking}

System-based thinking is the basic precondition of managerial work. In essence, it is about viewing on company as a whole, with its bounds, both with internal and external environment. The advantage of system-based understanding is being aware of the fact that every system can be part of a higher one, e.g. the Kosice Airport M.Sc. forms part of the Slovak air-route network or an airliner is part of an airline alliance etc. A subsystem is understood as separate unit within the company organizational structure. A rather simplified of systems-based thinking is in Fig. 1. 


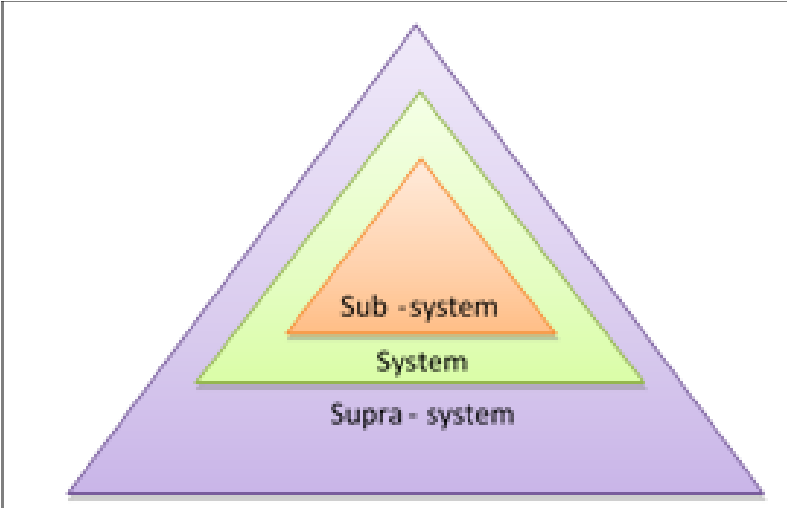

Figure 1 System -based view of a company.

Specific feature of a well-functioning system is in properly delegating control authorities at various levels. On top, medium and line -levels of management there are strictly defined vertical relations of subordination as well as those of cooperation at the horizontal determining cooperation at the given level. Specific managerial skill is the ability of looking at the company structure both from static and dynamic view. As a rule, static structure represents the organizational structure, whereas the dynamic one reveals the individual processes and flows.

\section{B. Balance-sheet analysis}

Balance-sheet analysis is a method that provides the manager an overview of company finance both from short-term and longterm aspects. (Stehlíková, 2001)

These are the areas which managers have often lack economic education. The assessment is based on analyzing the company balance sheet, thereby obtaining overview of its potentials for long-term and short-term financing. The balance sheet represents the central account of the company recording assets (physical property, intellectual property, money) and liabilities (owners' equity, long-term and short-term liabilities).

The assessment itself involves a two-stage process, at which the first, horizontal analysis evaluate the financial coverage of long-term assets and liquidity. Vertical analysis is about presenting the structure of assets and liabilities, see a typical structure of assets and liabilities in Table 1. (IATA,2014) The data compiled on the bases of several airport companies are subsequently subjected to both horizontal and vertical analyses.

\section{1) Horizontal analysis}

Results of the Horizontal analysis indicate sufficient coverage in terms of long-time financing - over-capitalization of long-term assets at Airport A, whereas insufficient coverage evident at Airport B, also termed as under-capitalization. In terms of short-term financing, the situation is rather similar as Airport A has more current assets available (50.000) than the payables known as short-term liabilities (30.000), whereas Airport B is lacking the necessary amount of short-term resources (only 20.000) to cover its short-term liabilities (as much as 30.000).
The abstract version presented in Table 1 is providing an appropriate view of the pre-conditions of long-term and shortterm financing of aviation companies, and the actions to be taken so as to prevent under-capitalization. Provided the company is unable to eliminate this negative status even when using external resources, things will become soon apparent on the poor financial status of the company as a whole. The fact can be reliably indicated and confirmed by the liquidity ration also revealing the amount of working capital available, not to mention the report on the cash flow.

Starting with the year of 2015 new rules of lowcapitalization came into being. Under certain conditions, part of cost interests from credits and loans will no longer be included into tax outlays. (Law 595/2003) For sure, this fact will affect the entire process of managers' decision-making. Further indicator to be considered is the EBITDA (Earnings before Interest, Taxes, Depreciation and Amortization), yielding the profit before excluding the aforementioned mentioned. (Sine, 2011) In practical life, there are various modifications to this indicator. Information necessary to calculate the EBITDA are available in the system of accounting and in the Profit and Loss account. Depreciation is recoded in account No. 551 Depreciation of tangible and intangible assets (line 18 of the Profit and loss account), costs of interests can be found on account No. 562 - Interest (line 39 of the Profit and loss account) and the indicator of Earning before Taxes is in line 59 of the Profit and loss account. The economic information mentioned are part of controlling sheets controllers usually submit to managers for further decision-making.

\section{2) Vertical analysis}

Vertical analysis performed as the second step reveals the structure of the individual items both assets and liabilities. When analyzing Long-term assets, one can often come up with Intangible assets, e.g. software, licenses, trademarks etc. On the Liabilities' side, the proportion of own capital, owners' equity, to the long.-term (loans) capital reveals not only the rate of indebtedness abuts also the rate of independence, or dependence of the company at decides-making related to long-term investments.

At short-term assets there are also items such as receivables, which exert negative influence upon company solvency. Knowing the structure of short-term liabilities helps us in identifying clients, suppliers, to whom we owe much to keep our operation going. The Index of liquidity is evaluable to defining the working capital, too, by subtracting current liabilities from current assets.

The comparison-based analysis of three most typical aviation companies, airport, airline and air navigation services, Table 2. reveals the different structures of assets and liabilities resulting from their different missions. It is worth-pointing out to higher proportion of current assets at airliners, making it more solvent for financing airport related charges. The situation is often negatively affected by high share of receivable, i.e. hitherto unpaid services for the airline companies. This phenomenon is not uncommon and severely damage liquidity, bringing it down to coca $50 \%$. 
TABLE I. BALANCE SHEETS OF AVIATION COMPANIES

\begin{tabular}{|c|c|c|c|}
\hline \multicolumn{2}{|c|}{ Airport Company } & \multicolumn{2}{|c|}{ Airliner } \\
\hline Assets & Liabilities & Assets & Liabilities \\
\hline 200 & 220 & 4.200 & 5.300 \\
\hline ITA & 180 & 798 & 5.238 \\
\hline TAA & 70 & 3.429 & 55 \\
\hline CA & 30 & 2.900 & \\
\hline FP & 20 & 1.158 & \\
\hline $\begin{array}{ll}\text { Strew } \quad 20\end{array}$ & STP & 1.591 & STP 2.969 \\
\hline $\begin{array}{ll}\text { Total } & 250\end{array}$ & 250 & $\begin{array}{ll}\text { Total } & 8.900\end{array}$ & 8.900 \\
\hline \multicolumn{2}{|c|}{ Air Navigation Services } & & \\
\hline Assets & Liabilities & & \\
\hline 59,2 & 83,5 & & \\
\hline ITA & 56,3 & & \\
\hline TAA & 27,2 & & \\
\hline 31,6 & 7,3 & & \\
\hline 21,2 & & & \\
\hline Strew & 6,7 & & \\
\hline $\begin{array}{ll}\text { Total } & 90.9\end{array}$ & 90,9 & & \\
\hline
\end{tabular}

TA - Total Assets or Total Liabilities

ITA- Intangible (LT)Assets

TAA - Tangible (LT)Assets

CA - Current Assets

FP - Financial Assets (+ securities.)

Strew - Short-term Receivables

STP - Short-term payables

The situation in the company providing air navigation services appears to be positive from both aspects of the analysis - vertical and horizontal as well. A fact that ensures favourable conditions for long-term and short time financing.

Also important are the differences in terms investment leverage of the various aviation companies. Apparently, airports demand the heaviest investments, with the majority of assets made up of buildings, taxiways and other inevitable infrastructure. The relatively balanced proportions at airlines and navigation service is marked with an amount of current assets equalling long term investments, as a result of obviously more business-oriented market they are involved in.

If the manager is unable to get oriented in the accounting practices, badly needing reliable survey on the variations of crucial data to the plan, then he or she is often pressed to make good use of the further method, the one termed as controlling.

\section{CONTROLLING}

Controlling provides the company a system of tools and information that enables goal-oriented management of the firm.
This was the reason why the method of controlling is bears closest relation to managing changes and simulation their impacts when taking several scenarios into consideration. Aviation companies, mostly airports and airliners are quite sensitive when reacting to changes in external factor coming from the environment, a status when management is required to act under the conditions of constant changes, known as contingency.

Useful tools of controlling are: planning (strategic, operative), reporting, costing of expenses and investments), benchmarking (interval, external). Managers are held responsible for decisions and results, and the controllers form in formation prepared in the documents submitted to them, providing a well-outlined and faithful reflection of the status quo. Controlling enables viewing a problem in a comprehensive way.

However, it can fail if it is based on wrong information or improper interpretation. As a matter of course, controlling is not a cure to all diseases, but makes everybody look for interrelated facts in via its criteria, such as return on investments, market share, cost reduction, cutting periods of receivables, efficient use and stabilization of the workforce etc. inevitably becoming helpful in revealing risks, analyses of variations to the plan or required course of action. It is related to the management of changes and the long-term success of the company. Basic differences between the actions of managers and controllers are illustrated in Table 3.

TABLE II. DIFFERENCES IN THE ACTIONS OF MANAGERS AND CONTROLLERS

\begin{tabular}{|c|c|}
\hline Manager & Co \\
\hline 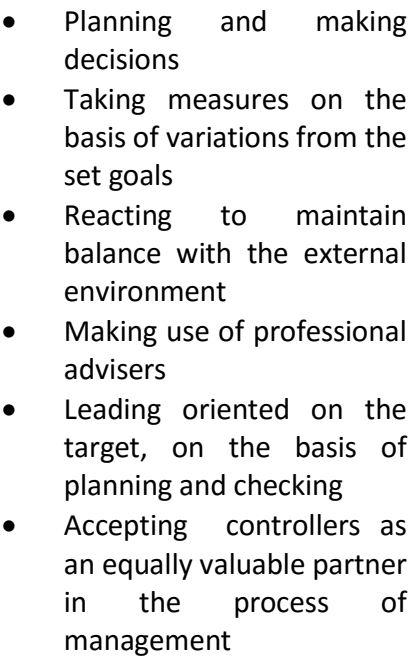 & $\begin{array}{l}\text { - Preparing documents for } \\
\text { planning and decision- } \\
\text { making } \\
\text { - } \quad \text { controlling the planning } \\
\text { process } \\
\text { Informing on the sizes and } \\
\text { causes of variations } \\
\text { Informing on changes in } \\
\text { the company environment } \\
\text { Offering } \\
\text { - } \text { advisory } \\
\text { Coordinating developing } \\
\text { and running systems } \\
\text { - Supporting coordination } \\
\text { Partner to the manager }\end{array}$ \\
\hline
\end{tabular}

Introduction of controlling in a company entails efficient handling of information resources, requiring a flexible system of information processing capable of adapting to changes and enabling the option of choosing the best quality information and establishing a company-based pool of information.

Controlling is useful mostly for the following reasons: 
- Need to be oriented in the internal and external environment,

- Need for a database and filtering information,

- Need for developers of variants to solutions,

- Need for developers of scenarios for variant solutions impacts,

- Fine-tuning of interest and unification of goals,

- Evaluation the fulfilment of pre-planned indicators,

- Analysis of the effects of entrepreneurial activities and decisions,

- Planning development of the company in consolidated and analytical indicators,

- Insuring the top-management towards revealing new business activities, which might bring about economic benefit to the company.

Unlike accounting and reporting performed in companies described by law and prepared for the external environment, controlling is mostly focused on monitoring company processes for internal purposes, thereby offering a new viewing of the actual operation regardless of the habitual links and routines. Further difference from the accounting is in controlling oriented towards the future and long-term success of the company. It scrutinizes areas of economics, logistics (product, logistics, purchase of supplies etc.), as well as to the quality of production, which often represents the most competitive advantage a company might benefit from. This is the very area, where carefully selected indicators help reveal the status quo in the areas to be focused on

\section{CONCLUSION}

System-based thinking, capability of ,seeing "the structure of company assets by analyzing the balance sheet as well as having the right tools for ex-ante, intermediate and ex-post as well as final assessment are important prerequisites on which a manager is offered useful information. The methods or approaches presented form a certain network of the company operation and its environment in the light of its economic results Currently, aviation companies operate in a turbulent exterior full of continuous changes. Their sensitivity to the external environment is fairly high. Absence of a right system of regular checks in the company economics supported by a suitable information system might prove fatal.

\section{REFERENCES}

[1] Drucker, P.: Innovation and Entrepreneurship. Practice and Principles. Routledche Classic, London and New York, 2015

[2] Honthyová, K.: Základy ekonómie a ekonomiky. Ekonóm, Bratislava, 2005

[3] Stehlíková, B. Finančná analýza podniku ako metóda finančného riadenia firmy. In: Acta montanistica Slovaca, roč. 6 (2001) 5, pp 112-119

[4] Synek, M.: Manažérska ekonomika. Grada Publishing, Praha 2011

[5] Szabo, S., Gavurová, B.: Vplyv vývoja svetovej ekonomiky na rozvoj leteckej dopravy, Aeronautika 2011, 20.-21.10.2011 Herl'any, Slovensko, Košice, TU, 2011, s. 1-6.

[6] Szabo, S., Hanák, P., Bučka, P: Economic analysis of selecting aviation equipment, New Trends in Aviation Development : proceedings of the 10 International Conference : September 13-14, 2012, Hotel Teledom, Košice : TU, 2012, s. 1-5.

[7] Tobisová, A., Szabo, S.: Ekonomika leteckého podniku 1, Košice, TU, 2014., $173 \mathrm{~s}$.

[8] Labantová, L., Begera, V.: Financial, operational and economic indicator of airline operators., Acta Avionica. roč. 16, č. 30 (2014), p. 1-5

[9] Zákon č. 595/2003 Z.z. o dani z príjmov v znení neskorších predpisov

[10] http://www.iata.org/publications/economics/Pages/industryperformance.aspx, forecast 2014 